\section{Financial Illiteracy and customer credit history}

\section{Danilo Braun Santos ${ }^{1}$ Humberto Gallucci Netto'}

${ }^{1}$ Federal University of São Paulo, Actuarial Science Department, Osasco, Brazil

\begin{abstract}
Purpose - We study how financial illiteracy affects the probability of a derogatory mark on the customer's credit history.

Design/methodology/approach - We use the National Survey on Financial Inclusion in Brazil together with information on financial instrument usage and spending provided by the head of the household. To estimate the impact of financial illiteracy on the probability of a derogatory mark we use a logistic model to compute the odds ratio.
\end{abstract}

Findings - Our main result is that financially illiterate individuals have between $57 \%$ and $143 \%$ more chance of having a derogatory mark. We find that age, income, expenses, and retirement positively affect the probability of a derogatory mark, while marriage has a negative impact. Gender does not have any impact over the probability of derogatory mark.

Originality/value - The study uses a new proxy for financial illiteracy and correlates it to the investment and debt decisions of a family using a unique dataset.

Keywords - Derogatory mark, financial illiteracy, financial literacy, capitalization bond, investment
Received on

07/31/2018

Approved on

03/07/2019

Responsible editor:

Prof. Dr. Joelson Oliveira

Sampaio

\section{Evaluation process:}

Double Blind Review

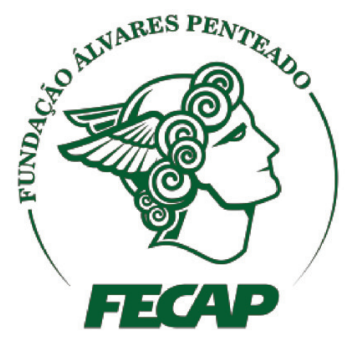

Revista Brasileira de Gestáo de Negócios

DOI: $10.7819 /$ rbgn.v22i0.4058 


\section{Introduction}

The Brazilian Central Bank and Serasa Experian have recorded increasing rates for the total number of credit defaults or payment delays over the last few years in Brazil. They estimate that there were 61.8 million Brazilians with a credit default or derogatory mark on their credit history in June 2018 (Serasa Experian, 2018). The increase in defaults raises concerns both for the country's financial and economic health.

Credit default problems are caused and intensified by financial illiteracy (Anderloni \& Vandone, 2010; Gerardi, Goette, \& Meier, 2010). In Brazil, most of the studies focus on the efficiency of the models for predicting default risk. Issues related to the causes of defaults and consumer behaviour patterns are barely studied by academics and the public sector. We tackle the relationship between financial illiteracy and defaults by using individual investment choice and consumer credit history.

Regardless of the degree of development of each country's financial market, financial education is precarious around the world. Individual defaults can lead to the financial exclusion of individuals (Lusardi \& Mitchell, 2011). Brazil has two credit default lists: SPC and Serasa. Derogatory marks increase the risk of debtors having their credit applications denied and being deprived of basic financial instruments and services, such as opening a checking account, thus causing social exclusion (Anderloni \& Vandone, 2010).

The Brazilian government created the National Financial Education Strategy (or ENEF, the acronym in Portuguese) through Federal Decree n. 7,397/2010 to spread financial education via a free and permanent program, capable of helping individuals make more autonomous and conscious financial decisions. The strategy was created through the interaction of eight government agencies and four society organizations. Together, they are part of the National Financial Education Committee
(CONEF). This initiative followed the lack of a structured financial education program before 2010 and highlights the importance of financial literacy to ease the growing credit default problem.

Measuring financial literacy is a complex issue. Lusardi and Mitchell (2011) understand that although it is important to assess the degree of financial literacy of individuals, in practice, it is difficult to explore how they process financial information and apply it to their daily decisions. Lusardi and Mitchell (2013, 2014) define financial literacy as the ability to understand economic information and make decisions about debt, investments, and financial planning. Moore (2003) argues that individual levels of financial literacy cannot be measured directly. For this reason, he recommends the use of proxies to identify whether the individual has satisfactory financial literacy. Therefore, this paper will follow Santos et al. (2018) and use capitalization bonds (títulos de capitalização, in Portuguese) as a proxy for financial literacy.

Capitalization bonds are often seen as an alternative with the same output as a savings account and most of the time they are sold using this argument. However, only part of the investment is effectively capitalized, the so-called capitalization quota, while in a savings account the entire value invested is capitalized. The main function of the interest rate in a capitalization bond is to define the percentage of the capital that the consumer will be entitled to in case of early redemption. If the bond is redeemed at maturity, the investor will receive the capitalization plus interest and will always receive $100 \%$ of the amount paid for the security. A financially literate individual will choose to invest in a savings account over a capitalization bond as a saving account has a superior yield and similar risk. We argue that only financially illiterate individuals will invest in capitalization bonds.

Our main hypothesis is that financially illiterate individuals have more chance of being added to a default list and having a derogatory mark. We use investment in capitalization bonds 
as a proxy for financial illiteracy to determine the probability of a derogatory mark on the customer's credit history. Our main result is that financially illiterate individuals have between 57\% and $143 \%$ more chance of having a derogatory mark on their credit history depending on the choice of controls. Despite being prohibited, joint sales of capitalization bonds and other bank products are common in Brazil. We use a bank loan dummy to reduce any possible endogeneity between capitalization bonds and a derogatory mark through joint sales.

We find other meaningful insights to explain the probability of a derogatory mark on a customer's credit history: older individuals have $16 \%$ more chance of having a derogatory mark, but this marginally decreases by $1 \%$; married individuals have $40 \%$ less chance; individuals with a higher income have 15\% more chance; formally employed individuals have a slighter higher probability than informally employed ones; and retired individuals have at least 178\% more chance of having a derogatory mark.

This article is organized as follows: Section 2 briefly describes the relationship between credit defaults, financial literacy, and capitalization bonds and how they work. Section 3 explains our methodology, data, and variables. Section 4 presents our results. Section 5 concludes the paper.

\section{Defaults, Financial Literacy, and Capitalization Bonds}

\section{I Brazilian defaults}

The Serasa Experian Consumer Default Indicator reflects default behaviour in Brazil and recorded a 1.98\% rise in defaulters in June 2018 compared to the previous year. The indicator found that $38 \%$ of all defaults are due to nonpayment of bank loans and leases, 31\% account for utilities, $11 \%$ for services, $13 \%$ for retail, and $7 \%$ for other reasons. In Brazil, $40 \%$ of the population has a default and on average each defaulter has four debts (Serasa Experian, 2018).

The Consumer Indebtedness and Default Survey (PEIC) is a survey of 18,000 consumers carried out monthly by the National Confederation of Commerce of Goods, Services, and Tourism (CNC). In May 2018, 59\% of households had debts involving credit cards, overdrafts, retail, personal loans, and insurance. The percentage of households that had outstanding debts was $24 \%$ of the total. In the survey, $10 \%$ of all families reported that they could not pay their debts and would remain in default (CNC, 2018).

\subsection{Financial literacy}

Financial illiteracy reinforces negative credit behaviour, such as excessive debt accumulation and high-cost borrowing (Lusardi \& Tufano, 2009), poor mortgage choices (Moore, 2003), losing one's home due to non-payment (Gerardi et al., 2010), poor investment choices (Bellofatto, D'Hondt, \& Winne, 2018), and suboptimal borrower behaviour (Bajo \& Barbi, 2018). Anderloni and Vandone (2010) understand that financial education plays a fundamental role as a preventive measure for controlling defaults, since it increases individuals' understanding of their financial decisions, making them better able to make financial choices. Gerardi et al. (2010) find a strong and significant correlation between a lack of knowledge in mathematics and mortgage defaults in the US, suggesting that financial illiteracy played an important role in the subprime crisis. Also, Garmaise (2015) shows that defaults are more likely for borrowers who give incorrect information when taking out loans, e.g., they report more assets than they really have, evidencing a lack of control over their personal finances.

Gathergood (2012) highlights a positive relationship between high levels of indebtedness and consumer behavioural issues, such as a lack of self-control and financial disorganization. Individuals lacking self-control and financial organization use quick and easy credit instruments such as credit cards and retail credit cards, not realizing the high costs and buying impulsively without worrying about future instalments. Also, Achtziger, Hubert, Kenning, Raab, and 
Reisch (2015) find that women are more prone to buying compulsively than men. Consumers may develop financial trauma, reducing their self-esteem and optimism in the face of financial questions (Mewse, Lea, \& Wrapson, 2010), which could reduce their wellbeing (Brown, Taylor, \& Price, 2005).

Measuring financial literacy is a complex issue. Lusardi and Mitchell (2011) understand that although it is important to assess the degree of financial literacy of individuals, in practice, it is difficult to explore how they process financial information and apply it to their daily decisions. Moore (2003) argues that each individual's level of financial literacy cannot be measured directly. For this reason, he recommends the use of proxies to identify whether the individual has satisfactory financial literacy. Therefore, this paper will use capitalization bonds as a proxy for financial literacy.

\subsection{Capitalization bonds (títulos de capitalização)}

Capitalization bonds are nominative securities, which can be purchased on a timeshare basis or on a unique payment basis. With this product the payments made by the subscriber are used to form the capital (capitalization quota), which is refunded at maturity plus interest. The remainder of the amounts paid are used to pay for sweepstakes and administrative expenses (Superitendência de Seguros Privados [SUSEP], http://www.susep.gov.br/2015, retrieved on 30 September, 2019). Currently, 17 million individuals have capitalization bonds. This market encompasses a broad universe of consumers, regardless of social class, income, or education (FenaCap, 2016).

Capitalization bonds are viewed and used by banks as a strategic tool to retain their relationship with their clients (Angst \& Abreu, 2007). They are a way to save money and still participate in sweepstakes and win prizes. The Brazilian National Capitalization Federation (FenaCap) refers to capitalization bonds as an effective alternative for those who do not have financial discipline and need to develop the habit of saving money (FenaCap, 2016).

Capitalization bonds cannot be considered as an investment, because they do not offer a return on the value invested despite being described as a way to save money (FenaCap, 2016). However, they are commonly compared to savings accounts, which are the most popular form of investment in Brazil. They are also a financial product that requires low contribution values, making it easier for people with little cash available to invest in them (Portocarrero, 2008). However, the difference between these two financial products is that savings accounts have an interest rate and monetary correction over the total invested while in capitalization bonds only part of the investment is effectively capitalized, the so-called capitalization quota. The main function of the interest rate applied is to define the percentage of the capital that the contracting party will be entitled to in the case of early redemption. When the bond is redeemed at maturity, it will always return the amount paid for the bond. Thus, the investor will never have a positive return.

According to the Organisation for Economic Co-operation and Development (OECD, 2013), individuals with lower levels of financial literacy are less aware of the alternatives and more susceptible to purchasing relatively high-cost products that do not match their real needs, and they are more likely to be subject to a misleading sale where the contract is poorly presented (such as in the case of the a capitalization bond contract). So, it is understood that the consumption of capitalization bonds identifies individuals with lower levels of financial literacy in Brazil.

It is necessary to consider a common practice of the Brazilian financial market, joint sale, which is capable of weakening the proxy at some level. Joint sale can be defined as a practice "which removes from the consumer the freedom and opportunity to acquire the good that he 
desires without being compelled to acquire another good or service" (Cravo, 2013). Joint sale represents a violation of free competition and is considered an abusive practice by the Brazilian Consumer Defence Code.

\section{Data and Methodology}

Our data is provided by the "National survey on the use of correspondents and financial inclusion in Brazil" from Bankable Frontier Associates and the Bill and Melina Gates Foundation carried out in 2012. The information was collected through a printed questionnaire and voluntary participation. The research sought to select a representative national sample of Brazilian households. Information on financial instrument usage and spending provided by the head of the household is more complete and accurate than an interview with a randomly selected individual (Cull \& Scott, 2010). Therefore, the oldest member of the household answered a set of initial questions to ensure a financially conscious interviewee was used. Our sample includes 2,885 respondents. For more information on this dataset see Sanford (2013).

This table presents a description of the variables

\begin{tabular}{ll}
\hline Variable & Description \\
\hline Derogatory mark & Binary variable indicating if the individual had a derogatory mark in SPC or Serasa in the last 12 months. \\
Capitalization bond & Binary variable indicating if the individual bought a capitalization bond in the last 12 months. \\
Bank loan & Binary variable indicating if the individual had a bank loan in the last 12 months. \\
Age & Number of years old. \\
Male & Binary variable indicating if the individual is a man. \\
Education & Number of years of education. \\
Married & Binary variable indicating if the individual is married. \\
Income & Monthly income (in Brazilian reais) \\
Expense & Monthly expenses (in Brazilian reais) \\
Formal employment & Binary variable indicating if the individual is in formal employment. \\
Informal employment & Binary variable indicating if the individual is in informal employment. \\
Retired & Binary variable indicating if the individual is retired or a pensioner. \\
Population & Number of inhabitants of the municipality. \\
Area & Municipality area (in km ${ }^{2}$ ). \\
\hline
\end{tabular}

We consider a default to be when the individual had a derogatory mark in the SPC or Serasa default lists in the last 12 months. Derogatory marks raise the risk of individuals having their credit applications denied by banks and not having access to basic financial instruments and services such as opening a checking account, which is necessary to deposit wages and any social benefits granted to the citizen and when lacking can lead to social exclusion (Anderloni \& Vandone, 2010).
Financial illiteracy is measured by the acquisition of capitalization bonds. Santos et al. (2018) argue that investing in a capitalization bond is irrational. They use the real example of holding a 36-month capitalization bond with a yield of $3.36 \%$ p.a. while one can invest in a savings account and collect nearly $20 \%$ after taxes in return in the same period. Capitalization bonds usually offer lotteries every month, where the prize can be money or a home appliance. 
Individuals choose lotteries to maximize the expected value, according to the expected utility theory (Neumann \& Morgenstern, 1947). Lopes and Oden (1999) use the SP/A theory to argue that risk choices are presented at two moments: during the risk-return assessment and when comparing the probabilities of achieving a level of aspiration. According to this approach, an individual might prefer to waive a $20 \%$ gain in a savings account and buy a capitalization bond, if their assessment of the probabilities leads to them somehow assuming that the chance of winning a prize is above a certain level. In other words, based on a personal desire and an assessment of the possibility of winning, the individual can behave as a "risk lover". The role of desire in choosing lotteries is evaluated by experiments in which the interviewees know the probability distributions of these lotteries (Lopes, 2016; Lopes and Oden, 1999).

\section{Descriptive Statistics}

\begin{tabular}{|c|c|c|c|c|c|}
\hline & Average & Standard Deviation & Minimum & Maximum & Observations \\
\hline Derogatory mark & 0,26 & 0,44 & 0 & 1 & 2885 \\
\hline Capitalization bond & 0,05 & 0,23 & 0 & 1 & 2885 \\
\hline Bank loan & 0,18 & 0,39 & 0 & 1 & 2885 \\
\hline Age & 46,98 & 15,53 & 16 & 94 & 2880 \\
\hline Male & 0,51 & 0,50 & 0 & 1 & 2885 \\
\hline Education & 6,56 & 4,23 & 0 & 16 & 2874 \\
\hline Married & 0,49 & 0,50 & 0 & 1 & 2885 \\
\hline Income & 1,166 & 2,058 & 0 & 36.000 & 2624 \\
\hline Expense & 363 & 1,139 & 0 & 38.123 & 2720 \\
\hline Formal employment & 0,26 & 0,44 & 0 & 1 & 2885 \\
\hline Informal employment & 0,34 & 0,47 & 0 & 1 & 2885 \\
\hline Retired & 0,24 & 0,43 & 0 & 1 & 2885 \\
\hline Population & 343.145 & 1.299 .324 & 1.212 & 8.916 .867 & 2885 \\
\hline Area & 2.644 & 6.129 & 17 & 62.846 & 2885 \\
\hline
\end{tabular}

Note. This table presents the summary statistics. Derogatory mark is a binary variable indicating if the individual had a derogatory mark in SPC or Serasa in the last 12 months; Capitalization bond is a binary variable indicating if the individual bought a capitalization bond in the last 12 months; Bank loan is a binary variable indicating if the individual had a bank loan in the last 12 months; Age is the number of years old; Male is a binary variable indicating if the individual is a man; Education is the number of years of education; Married is a binary variable indicating if the individual is married; Income is the monthly income (in Brazilian reais); Expenses is the monthly expenses (in Brazilian reais); Formal employment is a binary variable indicating if the individual is in formal employment; Informal employment is a binary variable indicating if the individual is in informal employment; Retired is a binary variable indicating if the individual is retired or a pensioner; Population is the number of inhabitants of the municipality; Area is the municipality area (in $\mathrm{km}^{2}$ ). The sample covers 2885 households.

Table 2 presents descriptive statistics for our variables. The questionnaire had 2885 respondents and $26 \%$ reported having a derogatory mark in the last 12 months while $5 \%$ bought a capitalization bond in the same period. 


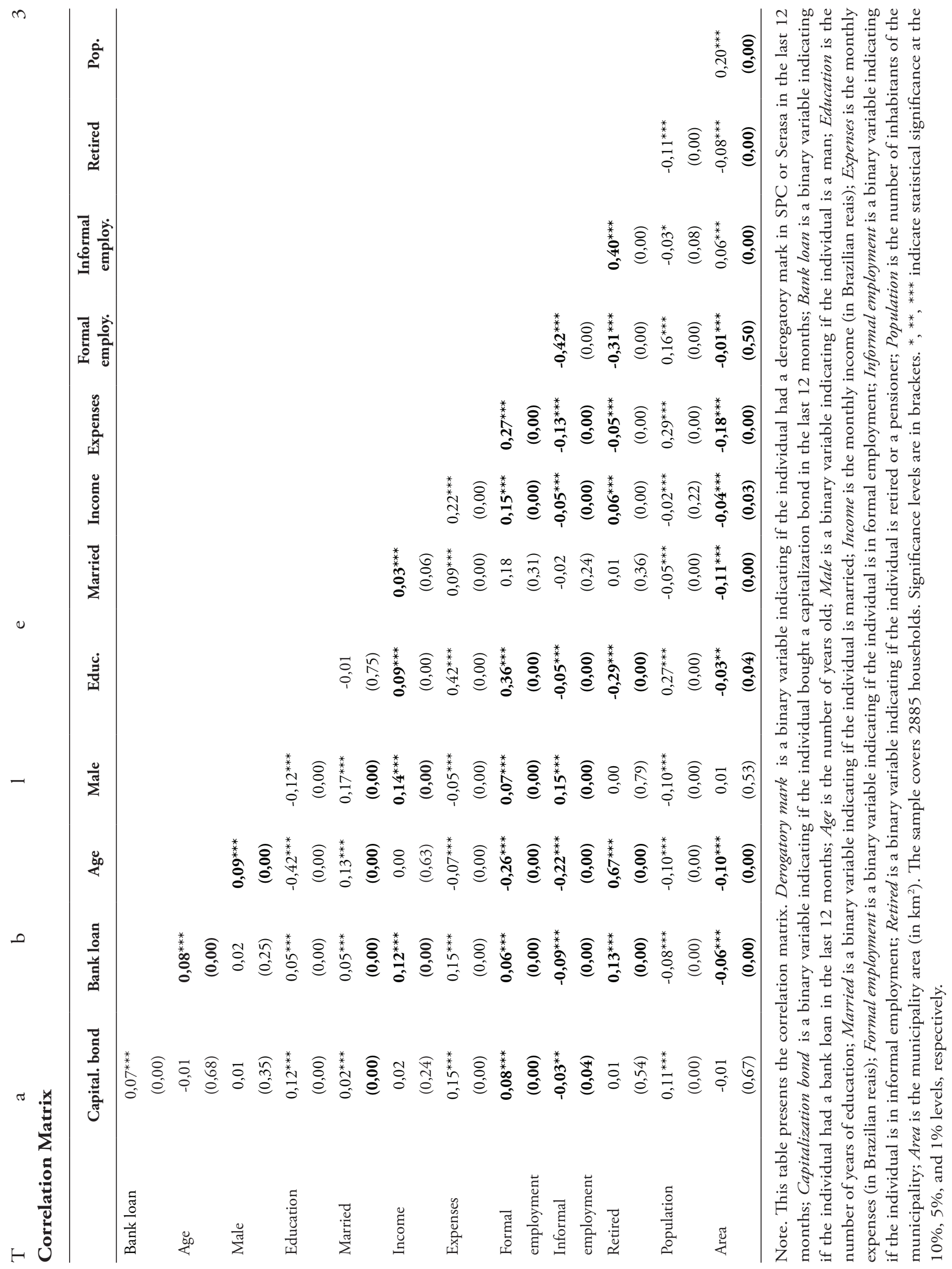


In our sample, the average age of the interviewees is 47 years, $51 \%$ are male, and $49 \%$ are married. In addition, $60 \%$ of the individuals are employed $(34 \%$ of the total are in informal employment) and $24 \%$ are retirees. The average monthly salary reported was 1,166 Brazilian reais (the legal minimum wage in 2012 was 622 Brazilian reais) and the average years of education is less than seven years.
Table 3 presents the correlation matrix of the explanatory variables. Capitalization bonds are correlated with bank loans, education, marriage, higher family expenses, and formal employment. Retired individuals have more bank loans, more income, and are employed more in the informal sector. Another interesting correlation is the positive relationship between income and formal employment.

a

b

1

e

Mean difference for individuals with a derogatory mark

\begin{tabular}{lccc}
\hline Derogatory mark & Yes & No & Difference \\
\hline Capitalization bond & 0,11 & 0,04 & $0,07^{* * *}$ \\
Bank loan & 0,25 & 0,16 & $0,09^{* * *}$ \\
Age & 42,93 & 48,38 & $5,45^{* * *}$ \\
Male & 0,49 & 0,52 & $-0,03$ \\
Education & 7,96 & 6,07 & $1,89^{* * *}$ \\
Married & 0,43 & 0,51 & $-0,08^{* * *}$ \\
Income & $1.393,18$ & $1.087,26$ & $305,92^{* * *}$ \\
Expenses & 511,88 & 311,42 & $200,46^{* * *}$ \\
Formal employment & 0,38 & 0,22 & $0,16^{* * *}$ \\
Informal employment & 0,33 & 0,35 & $-0,02$ \\
Retired & 0,16 & 0,27 & $-0,11^{* * *}$ \\
Population & 592.278 & 256.885 & $335.392^{* * *}$ \\
Area & 2.344 & 2.748 & -403 \\
Observations & 742 & 2143 & \\
\hline
\end{tabular}

Note. This table presents the average value for each variable separated by individuals with a derogatory mark and those without one. Derogatory mark is a binary variable indicating if the individual had a derogatory mark in SPC or Serasa in the last 12 months; Capitalization bond is a binary variable indicating if the individual bought a capitalization bond in the last 12 months; Bank loan is a binary variable indicating if the individual had a bank loan in the last 12 months; Age is the number of years old; Male is a binary variable indicating if the individual is a man; Education is the number of years of education; Married is a binary variable indicating if the individual is married; Income is the monthly income (in Brazilian reais); Expenses is the monthly expenses (in Brazilian reais); Formal employment is a binary variable indicating if the individual is in formal employment; Informal employment is a binary variable indicating if the individual is in informal employment; Retired is a binary variable indicating if the individual is retired or a pensioner; Population is the number of inhabitants of the municipality; Area is the municipality area (in km2). The sample covers 2885 households. *, **, *** indicate statistical significance at the $10 \%, 5 \%$, and $1 \%$ levels, respectively.

Table 4 presents the average value of each variable divided by the individuals with and without a derogatory mark. There are 742 individuals with a derogatory mark (26\% of the total). They invest $175 \%$ more in capitalizations bonds. Credit is more easily available for formally employed individuals with more income. The individuals with a derogatory mark have $56 \%$ more bank loans, $65 \%$ more expenses, $28 \%$ more income, and $72 \%$ more formal employment than the people without a derogatory mark. The average difference for education is unexpected, in that individuals with a derogatory mark are more educated (31\%) than those without a derogatory mark.

To estimate the impact of financial illiteracy on the probability of a derogatory mark, we estimate the following logistic model and compute the odds ratio: 


$$
\text { Degoratory }_{i}=\beta_{0}+\beta_{1} \text { Capitalization bond }_{i}+\beta_{\mathrm{n}} \text { Controls }_{i}+\varepsilon_{i}
$$

where:

Degoratory $i$ indicates if individual $i$ had a derogatory mark in SPC or Serasa in the last 12 months; Capitalization bond ${ }_{i}$ indicates if individual $i$ bought a capitalization bond in the last 12 months;

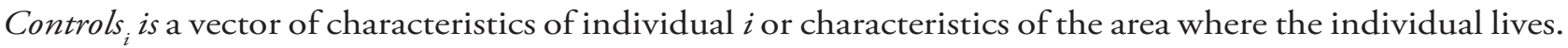

\section{Results}

Table 5 presents the odds ratio for our analysis of the impact of financial illiteracy on the probability of having a derogatory mark. There are five different regressions, where we use different sets of controls. Income, expenses, and education are self-reported variables and as they involve some uncertainty, we drop them from some of the regressions. Our main result is that individuals that bought a capitalization bond in the last 12 months have an increased chance of a derogatory mark, by as much as $143 \%$ compared to people who do not have this bond in their portfolios. Capitalization bonds are a significant explanatory variable in all regressions, despite changing the controls. In the worst-case scenario, individuals who bought a capitalization bond have $57 \%$ more chance of having a derogatory mark. This result is consistent with Santos et al. (2018), who found that capitalization bonds are the worst fixed income security that an individual can buy in Brazil and only financially illiterate individuals would acquire this asset. Thus, financially illiterate individuals would be more prone to delaying their payments and having a derogatory mark.

$\mathrm{T}$

a

b

1

e

\section{Regression results}

\begin{tabular}{|c|c|c|c|c|c|}
\hline Derogatory mark & (1) & (2) & (3) & (4) & (5) \\
\hline \multirow{2}{*}{ Capitalization bond } & $2,44^{* * *}$ & $1,85^{* *}$ & $2,47^{* * *}$ & $1,63^{*}$ & $1,57^{*}$ \\
\hline & $(0,75)$ & $(0,50)$ & $(0,73)$ & $(0,43)$ & $(0,41)$ \\
\hline \multirow{2}{*}{ Bank loan } & $1,56^{* *}$ & $1,72^{* * *}$ & $1,55^{* *}$ & $1,68^{* * *}$ & $1,66^{* *}$ \\
\hline & $(0,34)$ & $(0,36)$ & $(0,32)$ & $(0,33)$ & $(0,33)$ \\
\hline \multirow{2}{*}{ Age } & $1,17^{* * *}$ & $1,18^{* * *}$ & $1,15^{* * *}$ & $1,16^{* * *}$ & $1,16^{* * *}$ \\
\hline & $(0,05)$ & $(0,05)$ & $(0,04)$ & $(0,04)$ & $(0,04)$ \\
\hline \multirow{2}{*}{$\mathbf{A g e}^{2}$} & $0,99^{* * *}$ & $0,99^{* * *}$ & $0,99^{* * *}$ & $0,99^{* * *}$ & $0,99^{* * *}$ \\
\hline & $(0,01)$ & $(0,01)$ & $(0,01)$ & $(0,01)$ & $(0,01)$ \\
\hline \multirow{2}{*}{ Male } & 0,82 & 0,87 & 0,91 & 0,95 & \\
\hline & $(0,14)$ & $(0,14)$ & $(0,15)$ & $(0,15)$ & \\
\hline \multirow{2}{*}{ Education } & $0,95^{* *}$ & $0,96^{*}$ & 0,96 & 0,98 & \\
\hline & $(0,02)$ & $(0,02)$ & $(0,02)$ & $(0,02)$ & \\
\hline \multirow{2}{*}{ Married } & $0,59^{* * *}$ & $0,63^{* * *}$ & $0,58^{* * *}$ & $0,60^{* * *}$ & $0,58^{* * *}$ \\
\hline & $(0,10)$ & $(0,10)$ & $(0,10)$ & $(0,09)$ & $(0,09)$ \\
\hline \multirow{2}{*}{$\log ($ Income $)$} & $1,15^{* * *}$ & $1,15^{* * *}$ & & & \\
\hline & $(0,05)$ & $(0,05)$ & & & \\
\hline \multirow{2}{*}{$\log$ (Expenses) } & $1,16^{* *}$ & & $1,15^{* *}$ & & \\
\hline & $(0,08)$ & & $(0,08)$ & & \\
\hline \multirow{2}{*}{ Formal employment } & 1,74 & $2,07^{* *}$ & $1,74^{* *}$ & $1,97^{* * *}$ & $1,87^{* * *}$ \\
\hline & $(0,59)$ & $(0,71)$ & $(0,45)$ & $(0,49)$ & $(0,44)$ \\
\hline
\end{tabular}




\begin{tabular}{|c|c|c|c|c|c|}
\hline Derogatory mark & (1) & $(2)$ & (3) & (4) & $(5)$ \\
\hline \multirow{2}{*}{ Informal employment } & 1,59 & $1,80^{*}$ & $1,55^{*}$ & $1,62^{* *}$ & $1,62^{* *}$ \\
\hline & $(0,51)$ & $(0,59)$ & $(0,39)$ & $(0,39)$ & $(0,38)$ \\
\hline \multirow{2}{*}{ Retired } & $2,78^{* * *}$ & $3,21^{* * *}$ & $3,01^{* * *}$ & $3,17^{* * *}$ & $3,08^{* * *}$ \\
\hline & $(1,06)$ & $(1,20)$ & $(0,95)$ & $(0,96)$ & $(0,92)$ \\
\hline \multirow{2}{*}{$\log$ (Population) } & $1,17^{* * *}$ & $1,20^{* * *}$ & $1,17^{* * *}$ & $1,20^{* * *}$ & $1,19^{* * *}$ \\
\hline & $(0,05)$ & $(0,05)$ & $(0,05)$ & $(0,05)$ & $(0,05)$ \\
\hline \multirow{2}{*}{$\log ($ Area $)$} & $0,82^{* *}$ & $0,84^{* *}$ & $0,84^{* *}$ & $0,84^{* *}$ & $0,85^{* *}$ \\
\hline & $(0,06)$ & $(0,06)$ & $(0,06)$ & $(0,06)$ & $(0,06)$ \\
\hline Observations & 2,444 & 2588 & 2680 & 2845 & 2852 \\
\hline State dummy & Sim & Sim & Sim & Sim & Sim \\
\hline Wald chi ${ }^{2}$ & 199 & 198 & 202 & 205 & 202 \\
\hline Pseudo $\mathrm{R}^{2}$ & 0,19 & 0,18 & 0,17 & 0,16 & 0,16 \\
\hline
\end{tabular}

Note. This table presents the average value for each variable separated by individuals with a derogatory mark and those without one. Derogatory mark is a binary variable indicating if the individual had a derogatory mark in SPC or Serasa in the last 12 months; Capitalization bond is a binary variable indicating if the individual bought a capitalization bond in the last 12 months; Bank loan is a binary variable indicating if the individual had a bank loan in the last 12 months; Age is the number of years old; Male is a binary variable indicating if the individual is a man; Education is the number of years of education; Married is a binary variable indicating if the individual is married; Income is the monthly income (in Brazilian reais); Expenses is the monthly expenses (in Brazilian reais); Formal employment is a binary variable indicating if the individual is in formal employment; Informal employment is a binary variable indicating if the individual is in informal employment; Retired is a binary variable indicating if the individual is retired or a pensioner; Population is the number of inhabitants of the municipality; Area is the municipality area (in $\mathrm{km} 2$ ). The sample covers 2885 households. *, **, *** indicate statistical significance at the $10 \%, 5 \%$, and $1 \%$ levels, respectively.

Bank loan is a straightforward variable and one of the most common ways to have a derogatory mark is delaying or not paying a bank loan. Individuals with a bank loan have nearly $65 \%$ more chance of having a derogatory mark.

The life cycle theory by Modigliani and Brumberg (1954) states that individuals accumulate assets to maintain their way of life during their retirement years. So, a person would be more prone to acquiring a bank loan at earlier ages as they expect a higher income in the future. Thus, age is a consistent and significant variable. Older individuals have $16 \%$ more chance of having a derogatory mark, but this decreases by $1 \%$, as captured by the age-squared variable.

Gender is usually associated with asset choices (Fonseca, Mullen, Zamarro, \& Zissimopoulos, 2012; Lusardi \& Mitchell, 2011; OCDE, 2013). However, we do not find any relationship between gender and the propensity to have a derogatory mark. Family structure is relevant in explaining the propensity to have a derogatory mark: married individuals have $40 \%$ less chance of having one. One possible explanation is that married individuals are more conservative, or they may account for more than one income, diminishing the number and value of loans.

The income effect is ambiguous. Individuals with a lower income should be more prone to having a derogatory mark. However, our results show that a person with a higher income has $15 \%$ more chance of having a derogatory mark. Santos et al. (2018) argue that banks grant credit to individuals that have more chance of paying the loan. Our result can be interpreted more as a sign of credit restrictions in the Brazilian loan market than as a picture of the real demand for credit. The expenses effect has the expected result. Individuals with more expenses have 15\% more chance of having a derogatory mark.

Employment status provides another ambiguous result. Employed individuals should be less prone to having a derogatory mark. However, 
it is more difficult for an unemployed person to access the formal credit market and then have a derogatory mark. We should link employment status and income to better understand this result. In our sample, the average income is $R$ \$ 1,166 , which is almost two times greater than the legal minimum wage. So, the individuals in our sample have a low income and when employed they access the credit market, then they delay paying back or do not fully pay back the credit. As expected, formally employed individuals have a slighter higher probability of having a derogatory mark than informally employed ones. Despite a consistent positive coefficient, employment status is not significant for all the regressions.

The retired variable is consistently the biggest single factor to explain a derogatory mark.
The coefficient varies between 2.78 and 3.21 more probability of having a derogatory mark. Retired individuals have more access to the credit market and for lower income families they may represent the only income. This could imply that they are the only individual in a family with access to credit cards, increasing the probability of them having a derogatory mark.

Table 6 presents the average marginal effects for all regressions (Table 4). Individuals who invested in a capitalization bond have at least $8 \%$ more chance of having a derogatory mark and retired individuals have at least $18 \%$ more chance. This result corroborated the findings in Table 4 and Santos et al. (2018), in that financially illiterate individuals have more probability of having unpaid debt.

Marginal effects

\begin{tabular}{|c|c|c|c|c|c|}
\hline Marginal Effects & (1) & (2) & (3) & (4) & (5) \\
\hline Capitalization bond & $0,16^{* * *}$ & $0,11^{* *}$ & $0,16^{* * *}$ & $0,09^{*}$ & $0,08^{*}$ \\
\hline Bank loan & $0,08^{* *}$ & $0,09^{* *}$ & $\mathbf{0 , 0 8 * *}$ & $0,09^{* * *}$ & $0,09^{* *}$ \\
\hline Age & $0,02^{* * *}$ & $\mathbf{0 , 0 3}{ }^{* * *}$ & $\mathbf{0 , 0 3}{ }^{* * *}$ & $\mathbf{0 , 0 3} \mathbf{3}^{* * *}$ & $\mathbf{0 , 0 3}{ }^{* * *}$ \\
\hline $\mathrm{Age}^{2}$ & $-0,001^{* * *}$ & $-0,001^{* * *}$ & $-0,001^{* * *}$ & $-0,001^{* * *}$ & $-0,001^{* * *}$ \\
\hline Male & $-0,03$ & $-0,02$ & $-0,02$ & $-0,01$ & \\
\hline Education & $-0,01^{* *}$ & $-0,01^{*}$ & $-0,01$ & $-0,01$ & \\
\hline Married & $-0,09^{* * *}$ & $-0,08^{* * *}$ & $0,09^{* * *}$ & $-0,09^{* * *}$ & $-0,09^{* * *}$ \\
\hline $\log ($ Income $)$ & $0,02^{* * *}$ & $0,02^{* * *}$ & & & \\
\hline $\log$ (Expenses) & $0,03^{* *}$ & & $0,02^{* *}$ & & \\
\hline Formal employment & 0,10 & $\mathbf{0 , 1 3} 3^{* *}$ & $0,10^{* *}$ & $0,12^{* * *}$ & $0,11^{* * *}$ \\
\hline Informal employment & 0,08 & $0,10^{*}$ & $0,08^{*}$ & $0,09^{* *}$ & $0,09^{* *}$ \\
\hline Retired & $0,18^{* * *}$ & $0,21^{* * *}$ & $0,20^{* * *}$ & $0,21^{* * *}$ & $0,20^{* * *}$ \\
\hline $\log ($ Population $)$ & $\mathbf{0 , 0 3} 3^{* * *}$ & $\mathbf{0 , 0 3} \mathbf{3}^{* * *}$ & $\mathbf{0 , 0 3}{ }^{* * *}$ & $\mathbf{0 , 0 3}{ }^{* * *}$ & $\mathbf{0 , 0 3} \mathbf{3}^{* * *}$ \\
\hline $\log ($ Area $)$ & $-0,03^{* *}$ & $-0,03^{* *}$ & $-0,03^{* *}$ & $-0,03^{* *}$ & $-0,03^{* *}$ \\
\hline Observations & 2444 & 2588 & 2680 & 2845 & 2852 \\
\hline
\end{tabular}

Note. This table presents the average value for each variable separated by individuals with a derogatory mark and those without one. Derogatory mark is a binary variable indicating if the individual had a derogatory mark in SPC or Serasa in the last 12 months; Capitalization bond is a binary variable indicating if the individual bought a capitalization bond in the last 12 months; Bank loan is a binary variable indicating if the individual had a bank loan in the last 12 months; Age is the number of years old; Male is a binary variable indicating if the individual is a man; Education is the number of years of education; Married is a binary variable indicating if the individual is married; Income is the monthly income (in Brazilian reais); Expenses is the monthly expenses (in Brazilian reais); Formal employment is a binary variable indicating if the individual is in formal employment; Informal employment is a binary variable indicating if the individual is in informal employment; Retired is a binary variable indicating if the individual is retired or a pensioner; Population is the number of inhabitants of the municipality; Area is the municipality area (in km2). The sample covers 2885 households. *, **, *** indicate statistical significance at the $10 \%, 5 \%$, and $1 \%$ levels, respectively. 
To compare the probability of a derogatory mark between people with and without capitalization bonds, we need to control for differences in individual characteristics. So, we use our control variables to construct an optimal control sample. In Table 7, we use econometric matching methods developed by Heckman, Ichimura, and Todd (1997, 1998), Heckman and Robb (1986), and Rosenbaum and Rubin (1983).
For each person with a capitalization bond and another without one, we compute a propensity score via a Probit model, where the dependent variable is Capitalization Bond.

Table 7 suggests that owning a capitalization bond increases the chance of having a derogatory mark by at least $13 \%$. This result corroborates how financial illiteracy affects the probability of having an unpaid debt.

\section{Matching estimation}

\section{Estimator}

Near Neighbor $(n=1)$

Near Neighbor $(\mathbf{n}=\mathbf{1 0})$

Near Neighbor $(n=50)$

Near Neighbor $(\mathbf{n}=100)$

Gaussian

Epanechnikov

Difference in probability of derogatory marks between individuals with and those without capitalization bonds.
$0,13^{* *}$

$(0,06)$

$0,19 * * *$

$(0,05)$

$0,23^{* * *}$

$0,23^{* * *}$

$\mathbf{0 , 2 8 * * *}$

$(0,04)$

$0,25^{* * *}$

\section{Number of individuals with capitalization bonds \\ Number of individuals without capitalization bonds \\ $(0,04)$ \\ 156 \\ 2729}

Note. This table presents the difference in the probability of derogatory marks between individuals with and those without capitalization bonds using different estimators. Derogatory mark is a binary variable indicating if the individual had a derogatory mark in SPC or Serasa in the last 12 months. The matching variables are: Capitalization bond is a binary variable indicating if the individual bought a capitalization bond in the last 12 months; Bank loan is a binary variable indicating if the individual had a bank loan in the last 12 months; Age is the number of years old; Male is a binary variable indicating if the individual is a man; Education is the number of years of education; Married is a binary variable indicating if the individual is married; Income is the monthly income (in Brazilian reais); Expenses is the monthly expenses (in Brazilian reais); Formal employment is a binary variable indicating if the individual is in formal employment; Informal employment is a binary variable indicating if the individual is in informal employment; Retired is a binary variable indicating if the individual is retired or a pensioner; Population is the number of inhabitants of the municipality; Area is the municipality area (in $\mathrm{km} 2$ ). The sample covers 2885 households. *, **, *** indicate statistical significance at the 10\%, 5\%, and 1\%

levels, respectively.

Figure 1 presents the adjusted predictions for capitalization bond holders for each age.
Capitalization bond holders have more probability of having a derogatory mark, especially when the individual is aged between 45 and 55 years old. 


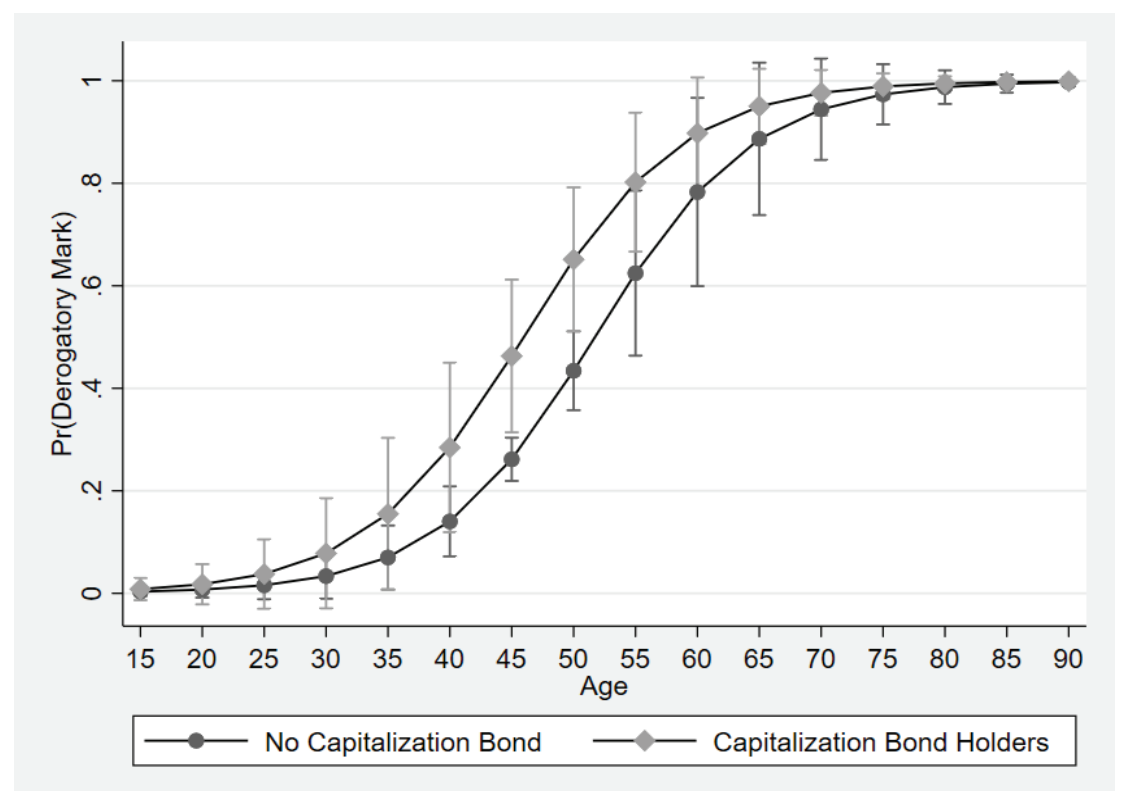

Figure 1. This graph presents the adjusted predictions for capitalization bond holders with 95\% confidence intervals.

\section{Conclusion}

Moore (2003) argues that individual levels of financial literacy cannot be measured directly. For this reason, he recommends the use of proxies to identify whether the individual has satisfactory financial literacy. In this paper we use a common bank product to measure financial literacy, following Santos et al. (2018) in using capitalization bonds as a proxy for financial literacy.

Our main result is that individuals that have invested in capitalization bonds have between 57\% and 143\% more chance of having a derogatory mark depending on the choice of controls. We use a bank loan dummy to reduce the possible endogeneity between capitalization bonds and derogatory marks through joint sales. The individual's inability to understand how savings and investments work has an impact on how they manage their debt.

We find other meaningful insights to explain the probability of a derogatory mark on a customer's credit history: older individuals have $16 \%$ more chance of having a derogatory mark, but this marginally decreases by $1 \%$; married individuals have $40 \%$ less chance; individuals with a higher income have 15\% more chance; formally employed individuals have a slighter higher probability of having a derogatory mark than informally employed ones; and retired individuals have at least $178 \%$ more chance of having a derogatory mark.

\section{References}

Achtziger, A., Hubert, M., Kenning, P., Raab, G., \& Reisch, L. (2015). Debt out of control: The links between self-control, compulsive buying, and real debts. Journal of Economic Psychology, 49, 141-149.

Anderloni, L., \& Vandone, D. (2010). Risk of over-indebtedness and behavioural factors. Department of Economics University of Milan Italy, Departmental Working Papers. Retrieved from https://www.researchgate. net/publication/46466330_Risk_of_overindebtedness_and_behavioural_factors

Angst, D., \& Abreu, J. (2007). Títulos de capitalização - Efeitos dos resgates antecipados na 
rentabilização e fidelização de clientes bancários em um banco no Paraná. Revista da FAE, 1O(2), 99-113.

Bajo, E. \& Barbi, M. (2018). Financial illiteracy and mortgage refinancing decisions. Journal of Banking and Finance, 94, 279-296.

Bellofatto, A., D’Hondt, C., \& Winne, R. de., (2018). Subjective financial literacy and retail investor's behavior. Journal of Banking and Finance, 92, 168-181.

Brown, S., Taylor, K., \& Price, S. W. (2005). Debt and distress: Evaluating the psychological cost of credit. Journal of Economic Psychology, 26(5), 642-663.

Cull, R., \& Scott, K. (2010). Measuring household usage of financial services: Does it matter how or whom you ask? The World Bank Economic Review, 24(2), 199-233.

CNC (2018). Pesquisa de endividamento e inadimplência do consumidor (Peic) - maio. Retrieved from http://cnc.org.br/editorias/ economia/pesquisas/pesquisa-de-endividamentoe-inadimplencia-do-consumidor-peic-maio-2018

Cravo, D. C. (2013). Venda casada: É necessária a dúplice repressão? Revista de Defesa da Concorrência, 1(1), 57-70.

FenaCap (2016). Capitalização: O que você precisa saber. Retrieved from https://issuu. com/confederacaocnseg/docs/t__tulo_de_ capitaliza o_-_o_que_

Fonseca, R., Mullen, K. J., Zamarro, G., \& Zissimopoulos, J. (2012). What explains the gender gap in financial literacy? The role of household decision making. Journal of Consumer Affairs, 46(1), 90-106.
Garmaise, M. J. (2015). Borrower misreporting and loan performance. The Journal of Finance, 70(1), 449-484.

Gathergood, J. (2012) Self-control, financial literacy and consumer over-indebtedness. Journal of Economic Psychology, 33(3), 590-602.

Gerardi, K., Goette, L., \& Meier, S. (2010, April). Financial literacy and subprime mortgage delinquency: Evidence from a survey matched to administrative data. Federal Reserve Bank of Atlanta (Working Paper 2010-10). Retrieved from https://www.frbatlanta.org/-/media/documents/ research/publications/wp/2010/wp1010.pdf

Heckman, J., Ichimura, H., \& Todd, P. (1997). Matching as an econometric evaluation estimator: Evidence from Evaluating a Job Training Programme. Review of Economic Studies, 64(4), 605-54.

Heckman, J., Ichimura, H., \& Todd, P. (1998). Matching as an econometric evaluation estimator. Review of Economic Studies, 65(2), 261-94.

Heckman, J., \& Robb, R. (1986). Alternative methods for solving the problem of selection bias in evaluating the impact of treatments on outcomes. Drawing Inference from Self-Selected Samples. Berlin: Springer - Verlag.

Lopes, L. (2016). Goals and the organization of choice under risk in both the long run and the short run: Hidden factors in the meltdown. In A. G. Malliaris, L. Shaw, \& H. Shefrin, The global financial crisis and its aftermath: Hidden factors in the meltdown (pp. 226-239). Oxford, UK: Oxford University Press.

Lopes, L. L., \& Oden, G. C. (1999). The role of aspiration level in risky choice: A comparison of cumulative prospect theory and SP/A Theory. Journal of Mathematical Psychology, 43(2), 286-313. 
Lusardi, A., \& Tufano, P. (2009). Debt literacy, financial experiences, and overindebtedness. Program on the Economics of Aging. National Bureau ff Economic Research, Cambridge, MA [Working Paper, No. 14808]. Retrieved from https://www. nber.org/papers/w14808.pdf

Lusardi, A., \& Mitchell O. S. (2011). Financial literacy around the world: An overview. NBER Working Paper Series, Working Paper No. 17107, Retrieved from http://core.ac.uk/download/ pdf/6358633.pdf

Lusardi, A. \& Mitchell O. S. (2013). Financial literacy and retirement planning in the United States. Journal of Pension Economics and Finance, 10(4), 509-525

Lusardi, A., \& Mitchell O. S. (2014). The economic importance of financial literacy: Theory and evidence. Journal of Economic Literature, 52(1), 5-44.

Mewse, A. J., Lea, S. E., \& Wrapson, W. (2010). First steps out of debt: Attitudes and social identity as predictors of contact by debtors with creditors. Journal of Economic Psychology, 31(6), 1021-1034.

Modigliani, F., \& Brumberg, R. (1954). Utility analysis and the consumption function: An interpretation of cross-section data. In F. Modigliani (Ed.), The collected papers of Franco Modigliani (pp. 388-436). London, UK: MIT Press.

Moore, D. (2003). Survey of financial literacy in Washington State: Knowledge, behavior, attitudes, and experiences. Pullman, WA: Social and Economic Sciences Research Center, Washington State University.
Neumann, L. J., \& Morgenstern, O. (1947). Theory of games and economic behavior. New Jersey, USA: Princeton University Press Princeton.

Organisation for Economic Co-operation and Development. (2013, June). Financial literacy and inclusion: Results of OECD/INFE survey across countries and by gender (Financial Literacy \& Education, Russia Trust Fund). Retrieved from https://www.oecd.org/daf/fin/financialeducation/TrustFund2013_OECD_INFE_Fin_ Lit_and_Incl_SurveyResults_by_Country_and_ Gender.pdf

Portocarrero, H. (2008). Títulos de capitalização e poupança financeira. Revista Conjuntura Econômica, 62(5), 64-67.

Rosenbaum, P., \& Rubin, D. (1983). The Central Role of the Propensity Score in Observational Studies for Causal Effects. Biometrika, 70(1), 41-55.

Santos, D. B., Silva, W., M. da, \& Gonzalez, M. (2018). Déficit de alfabetização financeira induz ao uso de empréstimos em mercados informais. Revista de administração de empresas, 58(1), 44-59.

Sanford, C. (2013, April 3). Do agents improve financial inclusion? Evidence from a national survey in Brazil. Bankable Frontier Associates. Retrieved from https://www.cgap.org/blog/do-agentsimprove-financial-inclusion-evidence-brazil

Serasa Experian. (2018). Indicador de inadimplência do consumidor. Retrieved from http://noticias.serasaexperian.com.br/ indicadores-economicos/inadimplencia-doconsumidor 


\section{Authors:}

1. Danilo Braun Santos, PhD in Business Administration at Fundação Getulio Vargas, São Paulo, Brazil. E-mail: danilo.braun@unifesp.br

\section{ORCID}

(iD) 0000-0001-8275-1059

2. Humberto Gallucci Netto, PhD in Business Administration at Fundação Getulio Vargas, São Paulo, Brazil. E-mail: humberto.gallucci@unifesp.br

ORCID

(iD 0000-0001-7905-1879

\section{Contribution of each author}

\begin{tabular}{lcc}
\hline Contribution & Danilo Santos & Humberto Gallucci \\
\hline 1. Definition of research problem & $\sqrt{ }$ \\
2. Development of hypotheses or research questions (empirical studies) & $\sqrt{ }$ & \\
3. Development of theoretical propositions (theoretical Work) & $\sqrt{ }$ \\
4. Theoretical foundation/ Literature review & $\sqrt{ }$ \\
5. Definition of methodological procedures & & $\sqrt{ }$ \\
6. Data collection & $\sqrt{ }$ \\
7. Statistical analysis & $\sqrt{ }$ \\
8. Analysis and interpretation of data & $\sqrt{ }$ \\
9. Critical revision of the manuscript & $\sqrt{ }$ \\
10. Manuscript Writing & $\sqrt{ }$ \\
11. Other (please specify which) & & $\sqrt{ }$ \\
\end{tabular}

